of my friends longer than until the London rebells shall demand them, only they will give them warning enough to run away, not suffering any of my forces to join with them; and for Mountrose, banishment in their wills must be his easiest condition. In a word, Montrevil now dissuades me as much as he did before persuade my coming to the Scotch army, confessing my knowledge of that nation to be much better than his. I have not now time to tell thee the rest of this business, particularly that I intend to dispatch an express to thee to-morrow with them, as likewise to shew thee that I neither spared pains, nor would have eschewed danger, to have made this Scotch conjunction, and also what course he means to take who is eternally thine,

Charles R.

\title{
XXIV.
}

Dear Heart,

Oxford, April 22nd, 1646.

Since Monday was fortnight, I have not received any letters from thee, which I only impute to the obstruction of passages, having failed of my ordinary intelligence from London, so that I am very doubtful how this will come to thee, which is the dispatch of the greatest importance, and the saddest, that I ever sent thee. Finding now my condition much worse than ever, by the relapsed perfidiousness of the Scots, which I so little suspected before Sunday last that I received account of that business from Montrevil, as I did not care what hazard I undertook for the putting myself into their army, for I resolved from hence to venture the breaking thro' the rebells' quarters (which, upon my word, was neither a safe nor easy work) to meet them where they should appoint; and I was so eager upon it, that, had it not been for Pr. Rupert's backwardness, I had tryed it without hearing from them, being impatient of delay. And when the rebells' forces came so thick about, so that I found that way of 
passing impossible, then I resolved and had laid my design how to go in a disguise. And, that no time might be lost, I wrote a letter to Mountrose to make him march up and joyn with them, in case he found by Montrevil, by whom I sent the letter, that they were really agreed with me.a

Thus thou seest that I neither eschewed danger nor spared pains to have made this conjunction with the Scots, which thou so much desiredst, and which I think the fittest for my affairs; and thou will as plainly see, by what secretary Nicholas sends thee, their base, unworthy dealing, in retracting of allmost all which was promised Montrevil from London, even to the being ashamed of my company, desiring me to pretend that my coming to them was only in my way to Scotland. But the pointing at their falshood must not make me forget to give Montrevil his due, who seriously hath carried himself in this business with perfect integrity (for the least slip of honesty in him had been my ruin), of which the burning of my warrant for the rendering of Newark being sufficient proof, if there had been no other.

All this doth plainly shew thee how my condition is, the difficulty of resolving of what to do being answerable to the sadness of it; but the renewing of thy advices upon all kind of suppositions hath in a manner directed me what to do. Wherefore, to eschew all kind of captivity, which, if I stay here, I must undergo, I intend (by the grace of Grod) to get privately to Lynn, where I will yet try if it be possible to make such a strength, as to procure honourable and safe conditions from the rebells; if not, then I resolve to go by sea to Scotland, in case I shall understand that Mountrose be in condition fit to receive me, otherwise I mean to make for Ireland, France, or Denmark, but to which of these I am not yet resolved; desiring, if it may be, to have thy judgement before I put to sea, to direct my course by. In the meantime, I conjure thee, by thy constant love to me, that if I should miscarry (whether by being taken by the rebells

a The letter to Montrose will be found printed in the Appendix. 
or otherwise), to continue the same active endeavours for Pr. Charles as thou hast done for me, and not whine for my misfortunes in a retired way, but, like thy father's daughter, vigorously assist Pr. Charles to regain his own. This thou canst not refuse to perform, knowing the reality of thy love to him who is eternally thine,

\section{Charles R.}

If I should go into Scotland, though I know thou wilt be willing that I swear Mountrose of my bedchamber, yet (to be punctual in my word to thee) I desire thy approbation to it, as also to the rest of my letter, with all possible speed. If thou hearest that I have put myself into Fairfax's army, be assured that it is only to have the fittest opportunity for my going to Lynn in a disguise, if not by other ways.

\section{$\mathrm{XXV}$.}

Dear Heart,

New-Castle, May 15th, 1646.

The necessity of my affairs hath made me send Jack Ashburnham unto thee, who at this present is the most (and with the greatest injustice) persecuted of all my servants, and meerly for his fidelity to me, which is so well known to thee, that I need neither recommend him to thy care, nor take the pains of setting down the present state of my affairs, and how they have changed since I came from Oxford, and why it is so long since I wrote to thee, referring all to his faithful relation, as likewise what I desire thee to do for my assistance; so transferring at this time the freedom of my pen to his tongue, I rest eternally thine,

\section{Chatles R.}

I owe Jack $£ 9,200$, which I earnestly recommend thou wouldst assist him in for his payment. 